\title{
Adequacy and Enforcement of Green Crimes: A Stinging Satire of the Nigerian Case
}

\author{
Okpa Ujong Bassey ${ }^{1 *}$, Amadi Anyakweh Miracle ${ }^{2}$, Ndubueze Ebere Lene $^{3}$ \\ ${ }^{1}$ LL.B (Calabar), B. L. (Yenagoa), Nigeria \\ ${ }^{2}$ B.Sc (Ebonyi), LL.B (Ilorin), B.L (Yenagoa), AICRM, AICMC, Nigeria \\ ${ }^{3}$ LL.B (Calabar), LLB, AICMC, Nigeria
}

\begin{abstract}
DOI: $10.36348 /$ sijlcj.2020.v03i01.005
| Received: 14.01.2020 | Accepted: 22.01.2020 | Published: 30.01.2020
\end{abstract}

*Corresponding author: Okpa Ujong Bassey

\section{Abstract}

Environmental deterioration has, over the years, produced unpleasant results with effects on health and economic development on earth. These health and economic ills are brought to the fore by pollution, inappropriate waste disposal, deforestation and wildlife extinction, most of which constitute criminal acts or omissions. In the wake of this, criminalizing environmental harm has become the mainstay of environmental legislation in Nigeria and even with the environmental laws and policies targeted at solving the problems, the situation in the country appears to be increasingly added-to, thanks to the weakness of the punitive measures and the sterility of the enforcement agencies in the country. This paper, therefore, scrutinizes the use of environmental law by selected enforcement agencies in Nigeria (federal and state levels alike) to curb environmental harm, prosecute green crimes, the methods of enforcement invoked by these agencies over the years, as well as the perceived challenges encountered in the enforcement of the relevant criminal provisions of the laws. Consequently, this paper proffers pragmatic solutions to the challenges of green crime enforcement in the country.

Keywords: Environment, crime, green crime, enforcement, enforcement agencies, environmental legislation, inadequate. Copyright @ 2020: This is an open-access article distributed under the terms of the Creative Commons Attribution license which permits unrestricted use, distribution, and reproduction in any medium for non-commercial use (NonCommercial, or CC-BY-NC) provided the original author and source are credited.

\section{INTRODUCTION}

With socio-economic and technological advancements has come an array of environmental menace, and it is humans and the species of flora and fauna that are at the receiving end of this environmental hazardousness. The trend of events in the environmental sector shows that activities which are harmful to the environment, and are carried out consciously and inadvertently by man, grow daily. In this path, man is gradually destroying the very means by which life is sustained. It is in a bid to curb these excesses that environmental harm has been criminalized over the years, irrespective of the differences in opinion as to which environmental issues should be criminalized [1].

Amidst the various international environmental conventions and treaties which Nigeria was signatory to, no serious effort had been directed toward making a concrete and unique set of rules and regulations to

\footnotetext{
${ }^{1}$ H. B. Spence, Paradox Lost; Logic, Morality and the Foundations of Environmental Law in the $21^{\text {st }}$ Century [1995], 20 Column. J. Env. L. L., 145 at 172
}

combat the menace of various pollutant elements in the country until 1988 when the Federal Environmental Protection Agency Act and the Harmful Waste (Special Criminal Provisions) Act [2] were promulgated in response to the koko waste case. Given the above, the Nigerian legislature, charged with the constitutional responsibility of enacting laws, brought into existence myriads of statutes with the goal of maintaining environmental integrity and preserving lives. Environmental protection has since been at the forefront of legislative and administrative measures in Nigeria, and prominent among these statutory enactments that attempt to comply with international treaty obligations are the National Environmental Standards and Regulations Enforcement Agency (NESREA) Act, the National Environmental Protection (Pollution and Abatement in Industries and Facilities Generating Wastes) Regulation, the Endangered Species Act3, the Nigeria Radioactive Waste Management Regulation, the National Oil Spill Detection and Response Agency

\footnotetext{
${ }^{2}$ Cap. H1, Laws of the Federation of Nigeria 2004
} ( ${ }^{3}$ Cap. E9, Laws of the Federation of Nigeria 2004) 
(NOSDRA) Act, the Nigerian Maritime Administration and Safety Agency (NIMASA) Act, the National Biosafety Management Agency (NBMA) Act, Associated Gas Re-injection Act, 4 Oil in Navigable Waters Act [5], Sea Fisheries Act [6], Territorial Waters Act [7], Environmental Impact Assessment Act (EIA) [8], Nuclear Safety and Radiation Protection Act [9] and the Petroleum Act [10]. This list is non-exhaustive. All these legislation, except the first, were enacted before the advent of the twenty first century although they have now been consolidated into the 2010 Laws of the Federation of Nigeria.

Most of the above mentioned laws boast of an abundance of criminal provisions with a plumage of minimal sanctions [11], while federal and state agencies like the National Environmental Standards and Regulation Enforcement Agency (NESREA), National Oil Spill Detection and Response Agency (NOSDRA), the National Biosafety Management Agency (NBMA), along with the Nigeria Police have been established and empowered to see to the enforcement of these laws and regulate the activities of individuals and companies (such as the carrying, depositing and dumping of harmful waste on any land or territorial waters, unlicensed effluent discharge, escape of oil into territorial water) that have a calamitous effect on man and the environment.

With all these, added to the strict liability nature of these crimes and the gross penalties provided under most of the extant laws, the question that begs to be answered hinges on the effectiveness, operability and functionality of these legal regimes [12]. Whether or not these agencies have been able to fulfill the purpose for their establishment and the crime trammeled in any way in the face of inadequate penalties is the focus of this paper and will therefore be appraised and expounded in it.

\section{Meaning, Nature and Categorization of Green Crime}

Green crime encompasses a broad list of illicit activities including illegal hunting and trade in wildlife, smuggling of ozone depleting substances (ODS), illicit

$\left({ }^{4}\right.$ Cap. A25, Laws of the Federation of Nigeria 2004)

${ }^{5}$ Cap. 06, Laws of the Federation of Nigeria 2004

${ }^{6}$ Cap. S4, Laws of the Federation of Nigeria 2004

${ }^{7}$ Cap. T5, Laws of the Federation of Nigeria 2004

${ }^{8}$ Cap. E12, Laws of the Federation of Nigeria 2004

${ }^{9}$ Cap. N142, Laws of the Federation of Nigeria 2004

${ }^{10}$ Cap. P10, Laws of the Federation of Nigeria 2004

${ }^{11}$ This is because the Nigerian State mostly utilizes the economic approach to environmental regulation.

${ }^{12}$ Emmanuel Onyeabor and Helen Agu, 'Economic Based Approach to Environmental Regulation as a Panacea to Effective Environmental Management in Nigeria' [2015] Journal of Law, Policy and Globalization, 8 trade of hazardous waste, illegal, unregulated and unreported fishing and illegal logging and trade in timber [13]. It also includes prohibited pollution of water and air and the production of noise beyound the acceptable decibel [ 14 ]. Popularly known as environmental crimes or 'green-collar crimes' [15] due to the fact that they are largely committed in the course of employment or business, green crimes are acts done in violation of those duties which an individual owes to the community in relation to the environment, the breach of which the law has provided that the offender shall make satisfaction to the public. Ekpo and Udoaka describe the phrase to be an act or omission which is harmful to the environment and which breaches an international or national environmental law which stipulates criminal sanctions [16]. Holistically, they are illegal acts which directly harm the environment and are liable for prosecution.

Public law does recognize the public interest, but difficulties arise from a lack of acceptance of the idea that the environment has some independent status or value as distinct from rights conferred on individuals and communities. Even criminal law struggles with green crimes, since it has often been pointed out by the courts that many of the offences created are not criminal in the true sense. This notion has been embraced by the English House of Lords even in the case of Alphacell Ltd $v$ Woodward [17] and the reasons for this are discussed in the proceeding paragraphs.

First, green crimes are aberrational in nature, in that they deviate from the general principle of criminal law that follows the elements of crime in holding a person liable for a crime committed. The main elements of a crime are the mens rea (mental element) and the actus reus (physical element) [18], concurrence of the mental and physical elements and injury or harm resulting therefrom. These elements must be present before a person can be convicted of any

13 These are the crimes recognized by international bodies like the G8, United Nations Environment Programme, European Union, Interpol and the United Nations Interregional Crime and Justice Research Institute.

${ }^{14}$ As rightly noted by Mokutima E. Ekpo and Edem E. Uduoka, 'Environmental Protection Laws in Nigeria: A Critique' [2016] Calabar Law Journal (17), 154, a harmful act or omission which affects the environment adversely only becomes criminal if it offends a legislation with criminal sanctions.

${ }^{15}$ K. E. Eman and G. Mekso, C. B. Fields, 'Crimes Against the Environment; Green Criminology and Research Challenges in Slovania' [2009] Journal of Criminal Justice and Security (4) at 52

${ }^{16}$ Ekpo and Udoaka, op cit at 157

${ }^{17}$ [1972] A.C 824.

${ }^{18}$ Mens rea is a latin word for guilty mind and actus reus is a latin word for guilty act. 
crime he is alleged to have committed or has been accused of committing. While the actus reus may be an act or an omission to act or even both, the mens rea may be the intention to act or omit to act including recklessness, negligence or accident. Picking an instance from Section 394 of the Criminal Code Act, "any person who kills any animal capable of being stolen with intent to steal the skin or carcass, or any part of the skin or carcass, is guilty of an offence". From this Section, killing of the animal is the actus reus and intent to steal the skin is the mens rea, and both elements must be proved to be present before the accused or offender will be held guilty for the offence.

However, green crimes do not require mens rea to attach to the element of actus reus. These are generally known as strict liability crimes. The liability is said to be strict because defendants will be convicted even though they were genuinely ignorant of one or more factors that made their acts or omissions criminal [19]. It is enough if the accused is reckless, negligent or the act or omission is merely unlawful. For instance, and like other federal and state enactments, it is an offence under the Oil in Navigable Waters Act for oil or any mixture of oil to be discharged into water from a vessel or to another vessel, from any place or land or to any place or land, or any apparatus used for transferring oil from or to any vessel. In this section, only the actus reus of the discharge is required to make the master or owner of the vessel, the occupier of that place on land or the person in charge of the apparatus guilty of the offence; no mens rea is necessary [20].

Additionally, there is a nexus between legitimate and illegitimate conducts in green or environmental crimes. This specifically applies to offences which are linked to the requirement of Environmental Impact Assessment (EIA). Whether or not an entrepreneur seeking to embark on a project has complied with the minimum requirement prescribed for EIA is a matter of degree. What is material may not be the substance ('what' is done) but the manner (the 'how') in which the act is carried out.

A third feature of green crimes is that, unlike traditional crimes which have been established and generally accepted for several years, its paradigm are novel and newly defined. The difference between what is acceptable and unacceptable in environmental crime

\footnotetext{
${ }^{19}$ This does not, however, mean that strict liability crimes make no room for defences. In fact, strict liability offences make room for the defence of mistake of fact (knowledge) and other defences. Only crimes of absolute liability do not allow for defences.

${ }^{20}$ Although liability is strict, there must be a causal link between the act 0r omission of causing the harm and the environmental harm complained of. Such was the reasoning of the House of Lords in Worthwell Ltd. $v$ Yorkshire Water Authority [1984] Crim. LR. 43
}

is constantly changing. Certain practices which were acceptable in the 1980s are now unsatisfactory. A clear example of such unacceptable conduct today is noise pollution [21].

Environmental crime in Nigeria may be generally categorized into the groups of serious specific offences and regulatory offences. Serious specific offences are mostly made in direct response to an offensive activity. An example is the establishment of the Harmful Waste (Special Criminal Provisions, etc.) Act in 1988 in response to the 1988 Koko incident in the then Bendel State [22]. Regulatory offences on the other flip embody preventive prohibitions, the scope of which covers the large number of cases in which criminal sanctions is imposed on persons who fail to comply with the administrative provisions of legislation like the National Environmental Standards and Regulations Enforcement Agency (NESREA) Act of 2007 or the Environmental Impact Assessment (EIA) Act of 1992.

\section{Statutory Framework for the Regulation of Environmental Crimes in Nigeria}

Before holistically driving directly into some of the statutory framework however, it is necessary to note two things. The first is that while some of the laws are framework legislation and incidental legislation, a whole lot of others are sectoral. While framework legislation are laws which are enacted in Nigeria with the overall environmental protection in mind [23] and sectoral legislation concerned with laws that are enacted for the protection of a sector of the environment [24], incidental legislation do not have environmental protection in mind and as such only a minuscule of their provision are relevant to environmental protection. Secondly, penalties in the various legislation only lie upon conviction.

\footnotetext{
${ }^{21}$ C. C. Ogah, 'A Critical Examination on the Effect of Noise Pollution on Environment and Health' [2013-15] The Calabar Law Journal (16), 52

${ }^{22}$ See section 1(2)(a)-(b) of the Harmful Waste (Special Criminal Provisions) Act where it is an offence for anybody to, without lawful authority, carry, deposit, dump or cause to be carried, deposited or dumped or is in possession for the purpose of carrying, depositing or dumping any harmful waste on any land or in any territorial waters or contiguous zone or Exclusive Economic Zone of Nigeria or its inland waterways and for anyone to transport or cause to be transported or is in the possession for the purpose of transporting any harmful waste.

${ }^{23}$ Edwin O. Ezike, 'Liabilities for Environmental Pollution Damage in Nigeria' [2010] The Journal of Private \& Property Law (28), 65. ${ }^{24} \mathrm{Ibid}$, at 73
} 
National Environmental Standards and Regulations Enforcement Agency (NESREA) Act

Established in 2007, the NESREA Act not only repealed the Federal Environmental Protection Agency (FEPA) Act [25], it also replaced it as the main environmental regulation statute in the country. The Act, which was signed into law by Late President Umaru Musa Yar'Adua, is an embodiment of laws and regulations focused on protection and sustainable development of the environment and its natural resources [26]. The Act creates NESREA as the regulatory body of the provisions of the Act and other Acts [27] and embodies regulatory provisions on water, air, noise, hazardous waste land and forest. These provisions are provided for between sections 20 and 27 of the Act.

By Section 20 of the Act, a person who violates the quality of Nigeria's air resources commits an offence and shall be liable to a fine not exceeding $\$ 200,000$ or to imprisonment for a term not exceeding one year or to both such fine and imprisonment and an additional fine of $\$ 20,000$ for every day the offence subsists [ 28 ]; and when committed by a body corporate, the body corporate shall be liable to a fine not exceeding $\$ 2,000,000$ and $\$ 50,000$ for every day the offence subsists [29]. Section 23 criminalizes the violation of the provisions of the water regulations under the Act to the tune of a fine not exceeding $\$ 50,000$ or to imprisonment for a term not exceeding one year or to both and an additional fine of $\$ 5,000$ for every day such violation continues; and if violated by a body corporate shall be liable to a fine not exceeding $\$ 500,000$ and an additional fine of $\$ 10,000$ for every day the offence subsists. Under Section 24, any person who violates the effluent limitations regulations made by NESREA commits an offence will be liable to a fine not exceeding $\$ 200,000$ or to imprisonment for a term not exceeding 2 years or to both such fine and imprisonment and an additional fine of $\$ 5,000$ for every day the offence subsists [30]; where it is violated by a body corporate, it shall be liable to a fine, not exceeding $\$ 1,000,000$ and an additional fine of $\$ 50,000$ for every day the offence subsists [31]. The penalties provided for in the Act are maximum penalties and therefore cannot be exceeded even though a minimum penalty can be given since the penalties are not mandatory either.

\footnotetext{
${ }^{25}$ By S. 36 of the NESREA Act, the FEPA Act is repealed.

${ }^{26}$ Murtala Ganiyu Murgan, An Appraisal of the Laws on Protection of Environment in Nigeria (Evan Prints 2015), 3 at 9

${ }^{27}$ See S. 1 of NESREA Act

${ }^{28}$ S. 20 (3) of the NESREA Act

${ }^{29}$ S. 20 (4) of the NESREA Act

${ }^{30}$ S. 24 (3) and (4) of the NESREA Act

${ }^{31} \mathrm{~S} .24$ (5) of the NESREA Act
}

Harmful Waste (Special Criminal Provisions) Act

By Section 1(2) of the Act, it is a crime for any person who, without lawful authority, carries, deposits, dumps or causes to be carried, deposited or dumped, or is in possession for the purpose of carrying, depositing or dumping, any harmful waste on any land or in any territorial waters or contiguous zone or Exclusive Economic Zone of Nigeria or its inland waterways; or transports or causes to be transported or is in possession for the purpose of transporting any harmful waste; or imports or causes to be imported or negotiates for the purpose of importing an harmful waste; or sells, offers for sale, buys or otherwise deals in any harmful waste. This section is the omnibus definition section of the Act.

The Act also makes for categories of offenders under the Act. By Section 2, a principal offender may be the person who actually did the act or makes the omission, did or omits to do any act for the purpose of enabling or aiding another person to commit the crime, aided another person in committing the crime, or who counseled or procures any other person to commit the crime [32] of which he will be liable to the same punishment as if he had himself carried out the act or omission [ 33 ]. Corporate bodies who violate the provisions of the Act will be liable to be proceeded against and punished accordingly [34]. Any person who is found guilty of committing or attempting to commit a crime under this Act is to be sentenced, on conviction, to imprisonment for life [35]. By Section 9, diplomatic immunity is not a defense to the crime committed under the Act, a crime of which the Federal High Court has exclusive jurisdiction [36]. It must be stated here that the exclusion of the defense of diplomatic immunity is commendable even though the exclusion of such a defense is not as important as putting to work what is already on paper.

\section{Nigerian Maritime Administration and Safety Agency (NIMASA) Act}

This Act came into effect in 2007 to, among other goals, protect the maritime environment, to promote maritime safety and security and establish NIMASA as the regulation and enforcement agency of the provisions of the Act. The Minister of transport is charged with the responsibility of making regulations as it relates to the Act.

\footnotetext{
32 S. 2(1) of Harmful Waste (Special Criminal Provisions) Act

33 S. 2(2) of Harmful Waste (Special Criminal Provisions) Act

${ }^{34}$ See S. 7 of Harmful Waste (Special Criminal Provisions) Act

${ }^{35}$ Ss. 6 and 8 of Harmful Waste (Special Criminal Provisions) Act

${ }^{36}$ See S. 13 of Harmful Waste (Special Criminal Provisions) Act
} 
Conviction for contravention of the provisions of the Act as it relates to the dumping of ship and shore generated waste in Nigerian waters and the removal of wrecks which constitute navigation risks and which is a threat to the marine environment [37] can be summarily or on indictment. What constitutes navigation risks and threat to the marine environment in section 44(1) has not been accorded with statutory definition and may be a matter of degree peculiar to the facts of each case as may be interpreted by the judiciary. In the words of Section 44 (3):

The regulations may provide that where a person contravenes a requirement under the regulations, he is guilty of an offence and is liable:

a) on summary conviction, to a fine not exceeding the amount as may be determined by the Agency; or

b) On conviction on indictment, to imprisonment for a term not exceeding two years or to a fine not exceeding the amount as may be determined by the Agency or to both statutory maximum.

A more general punitive provision is fashioned in Part thirteen of the Act. This Part houses section 58 which amidst of another provision makes any person who fails to comply with any provision of this Act or of any regulation made under the Act liable on conviction, to a fine not exceeding $\$ 1,000,000$ (one million naira) or to imprisonment for a term not exceeding twelve months, or to both such fine and imprisonment, and to a further fine not above $\$ 200,000$ (two hundred thousand naira) for every day the offence continues

\section{National Biosafety Management Agency Act}

The Act was enacted in 2015 to regulate the handling and containment of infectious microorganisms and hazardous biological materials. The Act establishes the National Biosafety Management Agency (NBMA) as the Agency to ensure the effective management of all components of Nigeria's Biosafety [38].

Section 35 of the Act is of the effect that any person, institution or body who imports, exports or releases for commercial purpose any genetically modified organisms without a prior permit of the Agency or contravenes the conditions of the grant of an approval or permit under the Act commits an offence liable to a fine of not less than $\$ 2,500,000$ or imprisonment for a term of not less than 5 years or both such fine and imprisonment (for an individual), or to a fine of not less than $\$ 5,000,000$ (for a corporate body or company). In addition to the liability of the company, the company's directors or officers will each be liable to a fine of not less than $\$ 2,500,000$ or committed to prison for a term of not less than 5 years or serve both

\footnotetext{
${ }^{37}$ S. 44 (1) of the NIMASA Act
}

${ }^{38}$ See S. 1(a) of the NBMA Act fine and prison term. It also is an offence under the Act to submit or supply false information in respect of any activity relating to genetically modified organism with prescribed punishment [39].

\section{Oil in Navigable Waters Act}

This 1968 Act was made to implement the terms of the International Convention for the Prevention of Pollution of the Sea by Oil of 1962. Sections 1 to 3 prohibit the discharge of oil into the waters of Nigeria by ships, vessels or any equipment used for transferring oil [40] and a person who contravenes these provisions will, upon conviction, be liable to a fine not in excess of $\$ 2,000$.

By section 7, failure to keep records warrants a fine not exceeding $\$ 1,000$, while keeping of misleading records calls for a fine not exceeding $\$ 1,000$ or imprisonment for a term not exceeding 6 months, or to both such fine and imprisonment. The liability imposed here is on summary conviction. It is submitted here that the penalties under this Act are epileptically inadequate and lack the capacity to compel obedience. The fact that the Act has since not been amended with focus on the penalties is a surprise given the dependence of the country on oil and the inevitable discharge of oil into her waters.

\section{Endangered Species (Protection, Conservation and Regulation of Trade) Act}

This Act, enacted in 1985, provides for the conservation and management of Nigeria's wildlife and the protection of some of her endangered species in danger of extinction as a result of over-exploitation. The effect of section 1(1) of the Act is that the hunting or capture of or trade in animal species which are threatened with extinction are absolutely prohibited [41]. The prohibition is not limited to those animals which are not necessarily threatened in the present with extinction but may become threatened if not controlled.

Penalties for violation of this Act are contained in Section 5. For animals in the 1st schedule, there is a fine of $\$ 1,000$ for first offenders and one-year

\footnotetext{
${ }^{39}$ See s. 36 of the NBMA Act

${ }^{40}$ According to Section 20 of the Act,"oil" means oil of any description, and includes spirit produced from oil of any description, and also includes coal tar, and any power conferred by any provision of this Act to prescribe descriptions of oil for purposes of that provision shall be construed accordingly. This could be construed to mean crude oil, fuel and lubricating oil and heavy diesel oil.

${ }^{41}$ These species are listed in the First Schedule of the Act and include, among others, chimpanzees, gorillas, lion, leopard, cheetah, dolphins, whales, crocodile, parrots, falcons. Schedule 2 of the Act lists these animals to include all monkeys except those listed in schedule 1, hippopotamus, ostrich, vulture etc.
} 
imprisonment for second and subsequent offenders. For animals in the 2nd schedule, there is a fine of $\$ 500$ for first offenders and 6 months imprisonment for second and subsequent offenders. Given the penalties provided, the question here becomes 'who cannot pay $\$ 1,000$ or \$500 without blinking?

\section{Nuclear Safety and Radiation Protection Act}

Enacted in 1995, the Act in its first section establishes the Nigerian Nuclear Regulatory Authority responsible for nuclear safety and radiological protection regulation in Nigeria. By Section 45 of the Act, contravention of any of the provisions is an offence and liable on conviction to a fine of not less than $\$ 100,000$ or more than $\$ 3,000,000$ or to imprisonment between two years and ten years or to both such fine and imprisonment. It is also an offence under the Act for an offence to have been committed with the consent or connivance of any person.

\section{Petroleum Act}

This 1969 enactment provides for the exploration of petroleum from the territorial waters and the continental shelf of Nigeria, and to vest the ownership of and all on-shore and off-shore revenue from petroleum resources derivable there from in the Federal Government and for all other matters incidental thereto. The Act grants oil exploration licenses, oil prospecting licenses and oil mining licenses. Importation, storage, selling, distribution of petroleum products and operation of licenses are made subject to holding of licenses. The Petroleum Regulations in Section 13 provides that no petroleum shall be discharged or allowed to escape into the water. Petroleum is also not to be allowed to escape into any inlet or drain communicating with a sewer [42]. Contravention of this Regulation attracts a fine of \$5,000 or imprisonment for no more than 6 months or both. Where the offender is a licensee, the license may also be cancelled [43].

\section{Cross River State Environmental Sanitation Enforcement (Urban Area) Law [44] \\ Enacted by the Cross River State House of} Assembly in 2003, this law provides for the enforcement of environmental sanitation within the State. Section 7 of the law mandatorily directs any person generating industrial waste in his tenement to provide a tank suitably holding such waste and to regularly dispose of such waste [45]. Such person is also mandated to provide a suitable waste treatment plant for treating the industrial waste emanating from the tenement before its discharge into any public

\footnotetext{
${ }^{42}$ S. 67 of the Petroleum Regulations 1974

${ }^{43}$ See S. 106 Supra.

${ }^{44}$ Cap. E6, Cross River State Laws, Federal Republic of Nigeria, Vol.4 (2004)

${ }^{45}$ See S. 7(1) supra
}

sewage [46]. Violation of the preceding section is an offence punishable with $\$ 2,000$ fine while a company will be liable to a fine of not less than $\$ 20,000$ [47].

Section 14 prohibits the deposit of toxic waste in waste receptacles, a breach of which attracts a fine of $\$ 3,000$ or an option of 6months imprisonment. A corporate body who violates the provisions of the law is to be fined $\$ 4,000$ and any officer who connived or consented to be fined $\$ 2,000$ with an option of imprisonment for 6months [ 48 ]. Once again, the inadequacy of the law seen through the penalties is still glaring.

\section{Lagos State Environmental Protection Agency (LASEPA) Law}

The law, enacted in 1996, hosts its prohibitions in section 22 where it prohibits, among others, actions such as the discharge or cause to be discharged, raw untreated human waste into any public drain, water- course, gorge, storm- water or unto any land; the discharge of any inadequately filtered and purified gaseous waste into the air. Contravention of the provision of the law is liability to a fine not exceeding five hundred thousand naira $\$ 500,000$ or a term of 5 years imprisonment in case of an individual and $\$ 1,000,000$ in the case of a Company or Corporate body $[49,50]$.

\section{Federal Agencies and the Enforcement of Green Crime in Nigeria \\ National Environmental Standards Regulation and Enforcement Agency (NESREA) \\ NESREA was created by Section 1 of the} NESREA Act as the main environmental regulating agency in the country after repealing the Federal Environmental Protection Act. Established on July 30,

\footnotetext{
${ }^{46}$ S. 7(2) supra

${ }^{47}$ By section 7(5) of the Law, any corporate offence committed under the section with the consent of a director, manager or secretary of the company, such officer of the company will be guilty of an offence and therefore liable to a fine of $\$ 2,000$ or to imprisonment for 6 months.

${ }^{48}$ See Section 34

${ }^{49}$ S. 30 (1) of the LASEPA Law

${ }^{50}$ By section 30 (1) (c) of LASEPA Law, any person who contravenes or fails to comply with any of the provisions of the LASEPA Law for which no penalty has been provided is guilty of an offence and shall on conviction be liable to a fine of two hundred and fifty thousand naira $\$ 250,000$ or a term of 5 years imprisonment or both in case of an individual, in case of an establishment, company or corporate body, it shall on conviction be liable to a fine of one million naira $\$ 1,000,000$. For any subsequent offence, the individual will be liable to a term of imprisonment for 10 years while the company or corporate body will be liable to a fine not exceeding $\$ 2,000,000$.
} 
2007 the agency is responsible for the enforcement of environmental standards, regulations, rules, laws, policies, guidelines and policies, with perpetual succession and a common seal and may sue and be sued in its corporate name [51] through the Director General of the Agency. The agency is charged with the responsibility of protecting and developing the environment, biodiversity conservation and sustainable development of Nigeria's natural resources as well as environmental technology. NESREA possesses broad enforcement powers; an officer of the agency may at all times enter and search with warrant issued by a court [52] any premises [53] excluding oil and gas facilities such as Maritime Tankers, Barge and Floating Production, Storage Offload (FPSO) [54]. It must be based on a reasonable belief that the premises are used for activities or storage of goods which contravene environmental standards or legislation, and not a mere belief, before such search can be proper. However, the propriety or otherwise of such search will not make the search invalid if and in fact the premises are used for activities or storage of goods which contravene environmental standards or legislation.

NESREA may in furtherance of investigation, through an officer of the Agency, take a sample or specimen of any article, seize and detain any article by means or obtain a court order to suspend activities, seal and close premises in relation to which he reasonably believes the provision of the Act or regulation has been contravened [ 55 ]. Thus, the enforcement powers conferred upon NESREA are far reaching, extending even to the closure of the premises used in contravention of the law.

Before going any further, two points must be stated here. First, NESREA is the main environmental protection agency in the country also responsible for the enforcement of other enactments including the Harmful

\footnotetext{
${ }^{51}$ See Section 1(2) of the NESREA Act

52 This contrasts with Section 10 of the Harmful Waste (Special Criminal Provisions) Act where environmental protection agencies are empowered to search without warrant. This new requirement of a search warrant by a court appears to be a recognition of the right to privacy guaranteed under section 37 of the Nigerian Constitution. The requirement of a search warrant also brings the NESREA Act in conformity with section 144 the Administration of Criminal Justice Act (ACJA) 2015 where a search warrant is required for a search to be lawful.

${ }^{53}$ Such premises include land, vehicle, tent, vessel and floating craft, inland water and other structure which the officer reasonably believes carries out activities or stores goods which contravene environmental standards or legislations for the purpose of conducting inspection, searching and taking Sample for analysis.

${ }^{54}$ See Ss.7, 8 and 30(1) (a) of the NESREA Act.

${ }^{55}$ See S. 30(1)(g) of the NESREA Act
}

Waste (Special Criminal Provisions) Act and the Environmental Impact Assessment Act, but not including the NOSDRA Act. The second point is that the Federal Government of Nigeria has developed 24 regulations through NESREA as subsidiary legislations whose provisions are to be administered by NESREA.

However, despite the wide provisions of the NESREA Act, the 24 subsidiary legislation and other legislative enactments in the state, the objectives and enforcement powers of the Agency (NESREA) and the daily criminal violation of legislation by Nigerians and foreign investors alike, the enforcement of the provisions of these legislation by the Agency appears not only invisible but non-existent. This justifies the dearth of environmental cases in the country, as no case has been brought before the court by the Agency since 2007. The same could be said of the defunct Federal Environmental Protection Agency who were the main environmental protection agency between 1988 and 2007.

\section{National Oil Spill Detection and Response Agency (NOSDRA)}

NOSDRA was established by the Federal Government when the issue of oil spill became a national problem. It was one of the recommendations of United Nations Environmental Protection (UNEP) following the level of pollution in the Ogoniland of Rivers State [56]. The NOSDRA Act creates NOSDRA [57] and clothes the agency with the responsibility of ensuring compliance of oil companies within Nigerian to environmental legislation and exerts penalties where there is default [58]. The Agency has, unsurprisingly, been unable to find its feet in this area for over 9 years. Between January 2006 and July 2010, for instance, the Agency had on record spills totaling about 3,725 times of which 495 spills occurred between January and July of 2010 alone. According to information available, Shell, Agip and Pipelines and Products Marketing Company (PPMC) are the worst culprits in terms of number spills, and the volume and frequency of spills have gone up.

Within 2006 and 2010, NOSDRA had only imposed fines two times on three organizations; Shell, Agip and PPMC. And sometime in 2010, it was reported that a fine of $\$ 1,000,000$ was imposed on the subsidiary of Agip Oil Company in Nigeria for spilling

56 Since its establishment in 2006, the Agency (NOSDRA) has been tracking spill dynamics in Nigeria. The agency has put together the National Oil Spill Contingency Plan (NOSCP), the Nigeria Environmental Sensitivity Index Map of the Coastal land stretching 55 kilometers inward and put in place a number of equipment and machines to monitor spills and facilitate clean-up and remediation.

${ }^{57}$ See S. 1 of NOSDRA Act

${ }^{58}$ See Ss. 5 to 7 of the NOSDRA Act. 
in Obrikom Omoku in Rivers State. This stride and achievement of NOSDRA is far from being laudable given the number of oil spillage in the country. Instead of being fixated on enforcing the provisions of the NOSDRA Act, NOSDRA has been involved in several role conflicts. One of such occurred between the agency and the Nigerian Maritime Administration and Safety Agency (NIMASA) in the December 2011 Bonga oil spill. Reports from NIMASA alleged that the spill was caused by Shell Petroleum Development Company (Shell) in which over forty thousand $(40,000)$ barrels of crude oil affecting an area of about one hundred and twenty (120) nautical miles of Nigerian coastline caused damages to the marine environment of Delta and Bayelsa States, affecting over one hundred and sixty eight $(168,000)$ people in 350 communities [59]. While the oil spill continued to cause havoc in the affected states, NOSDRA and NIMASA, two agencies charged with the responsibility of protecting the marine environment, continued to trade accusations and counter accusations as to which Agency was right in its assertions as to what had happened and what had been done by the spiller (Shell) [60]. Nothing was done to ameliorate the environmental damage caused by the spill to both the environment and the communities as the accusations and counter-accusations were going on, even though it was later reported [61] that a Federal Court in the country upheld the 3.6billion dollars fine imposed on Shell by NOSDRA. During this period, the spill had covered an area of 120 kilometers of the Nigerian coastline and was said to be spreading at one nautical mile per day [62].

\section{Nigerian Maritime Administration and Safety Agency (NIMASA) \\ The Nigerian Maritime Administration and} Safety Agency (NIMASA) is Nigeria's apex regulating agency established in 2007 by the NIMASA Act in section 3 to carry out the functions set out in section 22 of the Act; one of which is to control marine pollution.

59 <https://www.premiumtimesng.com/regional/southsouth-region/180674> accessed 29 October 2019

${ }^{60}$ While NOSDRA had claimed that the spill had been contained by Shell and praised it for a job well done, NIMASA on the other hand accused Shell of having behaved irresponsibly as its response to the spill was below international standard.

${ }^{61}$ Ben Ezeamalu, 'Shell Liable to 3.billion dollars fine over Bonga Oil Spill, Nigerian Court rules' Premium Times (21 June 2018) http://www.premiumtimesng.com/news/headlines/2731 77-shell-liable-to-3-6-billion-fine-over-bonga-oil-spillnigerian-court-rules.html> accessed on 29 October 2019.

${ }^{62}$ Emmanuel Onyeabor and Helen Agu, 'Economic Based Approach to Environmental Regulation as a Panacea to Effective Environmental Management in Nigeria' [2015] Journal of Law, Policy and Globalization at 10
Closely related to that function is the enforcement of the provisions of the Cabotage Act 2003 under paragraph I of the same section. Despite claiming that enforcement of cabotage policies led to the creation of 7,000 jobs for Nigerian seamen and raising cabotage trade by 32 percent in just six months, the Agency's Director-General, Dakuku Peterside, admitted that the agency has failed in the implementation of the cabotage laws of the country [63].

Against this backdrop, the chief and sole goal of NIMASA over the years has been the provision of jobs for qualified Nigerians in the maritime sector and providing revenue for the Federal government as against paying the most minute of attention to ensuring that the lives and inland waters of the country are safe through the enforcement of the punitive provisions of the Act. It is no surprise that jurisdictional provision of the Coastal and Inland Shipping (Cabotage) Act as enshrined in section 41 of the Act have not been invoked despite liability under the Act being strict [64].

\section{The National Biosafety Management Agency (NBMA)}

The National Biosafety Management Agency is established by the National Biosafety Management Agency Act 2015 to provide regulatory framework to adequately safeguard human health and the environment from potential adverse effects of modern biotechnology and genetically modified organisms, while harnessing the potentials of modern biotechnology and its derivatives, for the benefit of Nigerians [65]. By section 1(2) of the Act, this Agency which may sue and be sued in its corporate name [66], is the national authority on Biosafety in Nigeria. In section 40 of the Act, it is the Federal High Court that has jurisdiction to try the offences the Agency is responsible for regulating. However, till date, no charge has been drafted before the said Court by the Agency.

\section{States Institutions and the Enforcement of Green Crime in Nigeria}

The various states in Nigeria not only have laws with whom they regulate the environment, they additionally have agencies created with the primary objectives of implementing and enforcing the provisions of these enactments. These agencies are popularly known as State Environmental Protection Agencies (SEPA) and their establishment has been justified thanks to the substantial degree of activities touching the use of these natural resources and the

\footnotetext{
$63<$ https://www.businessamlive.com//no-success-insight-of-nigerias-cabotage-implementation-as-nimasaadmits-flaws> accessed 12 January 2020

${ }^{64}$ See section 40 of the Coastal and Inland Shipping (Cabotage) Act 2003

${ }^{65}$ Retracted from <http://www.nbma.gov.ng/about-us/> accessed 28 April 2019.

${ }^{66}$ See S. 1(1) (c) of NBMA Act
} 
negative environmental fallouts taking place in the States and localities [67]. However, the enforcement of these laws by the various agencies solely does not justify the promulgation of the laws and the establishment of the agencies. For instance, the Kwara State Environmental Protection Agency (KWEPA) is the body created by Kwara State government through the KWEPA Act and empowered by the laws of the state to see to the prevention and control of environmental pollution in many spheres. The body is also saddled with responsibility of regulating hazardous waste disposal and maintaining clean environment in the state. However, even the infinitesimal efforts of these agencies are yet to be seen in the areas of water and air pollution, not because the populace is blind but that there is nothing to behold.

In Cross River State, it was reported [68] that the Cross River Sate government, through the agency of the Ministry of Environment - the Green Sheriff [69], dragged 19 firms (including hotels, fuel stations and bakeries), traders and some residential occupants to court over sanitation offences. Some of these firms and individuals include Pearl Suite Hotel, Axari Hotel, Channel View Hotels, Mobil Filing Station by SPC Junction, Clear Line Publication, the Chairman of the Occupiers of Suya Acade, Adrian's Bread Factory, Ezenwa Welding and Fabrication, every business operator at Nsefik Layout, Mercy Shop \#82 IBB Way Calabar and the owner and occupiers of \#12 Beecroft Street Calabar [70]. The offences included, among others, failure to fumigate premises, allowing of condemned diesel oil into public drain and public road, allowing heaps of rumbles in the premises, failure to remove cobwebs from the walls of building and failure to provide standard waste bin. Unfortunately, the case was adjourned71 and yet to be heard of ever since. On the other hand a dearth of criminal cases involving the Cross River State Environmental Protection Agency, the agency saddled with the responsibility of ensuring and implementing environmental protection laws in

67 O. Fagbohun, "Reappraising the Nigerian Constitution for Environmental Management" [2002] Addis Ababa University Law Journal (1), 1.

68 'Cross River State Government Drags 19 Firms, Residents to Court' (Calabar, April 15 2018) <http:// calabarreporters.com/33340/> accessed 18 April 2018

${ }^{69}$ The Green Sheriff has as its main functions the protection and sanitation of the environment as well as the preservation and sustainable managSement of forest resources. It has the power to arrest and sue in its name even though its officers are not meant to be with firearms. The agency commenced operation from Monday the $8^{\text {th }}$ of May 2017.

70 'Cross River State Government Drags 19 Firms, Residents to Court', op. cit.

${ }^{71}$ Ibid
Cross River State [72] which can sue and be sued in its corporate name [73] points to a sterile enforcement. Little wonder the streets of Calabar are littered with refuse while the provisions of the Cross River State Indiscriminate Dumping of Refuse (Prohibition) Law remain only on black and white; a blueprint at best.

Also, the Lagos State Environmental Protection Agency (LASEPA), the agency responsible for regulating environmental laws in Lagos state, has recorded very little despite having the power to apply enforcement measures to combat environmental degradations in manufacturing premises and government operations in a commercial State like Lagos where green crime is at the apex and constantly on the rise [74].

\section{Other Remedies and the Enforcement of Green Crime}

The court's jurisdiction in respect of environmental protection can be invoked by either public litigation or private litigation [ 75 ]. Public litigation of green crimes is mainly conducted by environmental agencies through the Director General of NESREA on behalf of the Attorney General of the Federation. And instead of being an addition, the enforcement agencies have totally resorted to using civil remedies as a substitute to enforcing green crimes. Such civil remedies include forfeiture and closing down of the premises used for the contravening activity and the payment of damages or costs as a result of the violation of any of the environmental protection laws. Under Section 4 of the Associated Gas-reinjection Act for instance, any oil-and-gas-producing company that flares gas produced in association with oil without the written permission of the Minister of Petroleum is to be ordered to repair or restore any reservoir in the field in accordance with good oilfield practice in addition to the penalty specified. Also, by Section 62 of National Biosafety (Implementation, etc) Regulations 2017 [76], the user who is responsible for pollution bears the remediation cost of the environmental damage caused or likely to be caused. This method of enforcing environmental law deviance is in line with the polluter pays principle. The idea of the polluter-pays principle is

\footnotetext{
${ }^{72}$ See Section 2 of the Cross River State Environmental Protection Agency Law, Supra. The Ministries of Environment in the various states of the country are dogmatic to their enforcement functions too.

73 See section 1(2) of the Cross River State Environmental Protection Agency Law.

${ }^{74}$ See S. 8 (d) of the LASEPA Law

${ }^{75}$ S. G. Ogbodo, 'The Role of the Nigerian Judiciary in the Environmental Protection Against Oil Pollution: Is It Active Enough?' <http://nigerianlawguru.com> accessed 28 October 2019.

76 The National Biosafety Regulations, 2017 is a regulation made pursuant to the National Biosafety Management Agency Act 2015
} 
based on the notion that the polluter should pay for his pollution or the cost of cleanup rather than the tax payer or the public. As part of a set of broader principles to guide sustainable development, this principle has also been specifically applied to emissions of greenhouse gases which cause climate change. This principle makes the polluter to pay only for the result of the visible damage caused and nothing more.

The court's jurisdiction in respect of environmental protection may also be invoked by private litigation. Private litigation relates to injury to private property and other personal rights and public interest litigation or "citizen standing". Most of the actions in Nigerian courts with respect to environmental crime law, particularly oil pollution, are founded on the injury to private or communal property and other personal rights in civil law as against criminal law. Section 23 of NESREA Act mandates NESREA to make regulations for protecting public health or welfare and enhance the quality of water, and any person who is discovered to have violated the provisions is to be criminally liable under the section therein. However, the wordings of this section have since been translated in private actions through the civil procedures of nuisance, negligence, trespass and the strict liability tort of the rule in Rylands $v$ Fletcher. In the popular nuisance case of Abiola $v$ Ijeoma [77] for instance, the plaintiff successfully sued the defendant whose rearing of chicken emitted offensive odour that made sleeping unbearable for the plaintiff. In another case of Shell Petroleum Development Company (Nig.) Ltd v Chief G.B.A Tiebo VII \& ors [78], the trial court awarded damages for the loss of raffia palms and drinking water as a result of the crude oil spill on the land, creeks and lakes of the plaintiff. Also, in Halsey $v$ Esso Petroleum Co. Ltd [79], the plaintiff successfully sued the defendant factory who emitted acid snots and excessive noise which disturbed the peace of the plaintiffs.

\section{CONCLUSION}

The penalties created under virtually all the Nigerian laws examined are a mockery of the offences created, making it possible for the offenders to even pay in advance for future offences. Take for instance the $\$ 50,000$ deterrent fine option for allowing petroleum to escape into any inlet or drain communicating with a sewer under section 106 of the Petroleum Act and the $\$ 500$ and $\$ 1,000$ fine for the contravention of the Endangered Species Act. While the punitive sanctions in some of legislation like the Harmful Waste Act are recommendable, a host of others are grossly and ridiculously inadequate; even the recommendable ones lack prosecutorial enforcement. A system which ought to send deterrent message has been perverted. It is our

\footnotetext{
${ }^{77}$ [1970] 2 All NLR 768

78 [2005] LPELR-SC.9/1999

79 [1961] 1 WLR 683
}

submission that the most effective way of ensuring that the deterrent message is not trampled upon is amending the various laws to eliminate the options of fine while also stipulating more severe prison terms; for nothing works better at getting managers and directors of companies to pay attention to environmental compliance than the prospect of going to jail [80]. But such imprisonment term should not be as ridiculous as that provided for in Section 44 (3) (b) of the NIMASA Act where the maximum penalty for contravention is two years imprisonment.

Given the fact that green crimes are strict liability in nature requiring no corresponding mental element for conviction, one would literarily expect, as was anticipated, a humungous number of cases on environmental degradation coming before Nigerian courts. Such expectations, whether clothed in anticipation or believe, can only be found in the confines of failures, deferred hopes and disappointments; failures sprouting from the dormancy of legislative framework resulting in loss and endangerment of lives, bleakness of health, and the extinction of the species of fauna and flora. Such was the result of the ineffective enforcement of the Quarantine Act whose violation led to the outbreak of Ebola virus disease in 2014, killing many Nigerians in the process [81], And except steps are taken to give breath and a working command to these legislation, the lives of the residents of Nigeria and the species of plants and animals may not live long to testify to the constantly degrading nature of our environment.

We do not cry because of a dearth of environmental cases coming before our courts daily. Our cry is that the environmental cases which appear before the court are instituted by private individuals and in the realm of civil procedure. It, therefore, does not end in the fact that the court's jurisdiction in respect of environmental protection can also be invoked by private litigation, it extends to the truth that such jurisdiction have chiefly been triggered by private litigation. Such was the case in Jonah Gbemre v Shell PDC Ltd and Ors [82] where the Federal High Court, in granting leave to the defendant to institute an action in a representative capacity and to apply for an order enforcing the fundamental rights to life and human dignity as provided by the Constitution and reinforced in the African Charter on Human and People's Right, gave an order restraining the respondents from further gas flaring and to take immediate steps to stop the further flaring of gas in the community. This is akin to the

${ }^{80}$ W. L. Hubbel at EPA's Criminal Enforcement Program; Hearing before the subcommittee on Energy and Commerce, 1903d, Cong $1^{\text {st }}$ Sess 173, 1993

81 The Guardian (Monday August 4 2014) <http://www.theguardian.com/world/2014/aug/04/docto r-nigeria-ebolavictim> accessed 1 May 2018

${ }^{82}$ [2005] Suit No. FHC/B/CS/53/05. 
remedies already mentioned in this paper. NESREA and other environmental enforcement agencies have taken back seats in dispensing with their functions of inspecting, searching, investigating or arresting the perpetuators of the green crime and prosecuting them. The situation is moreo pitiable for Nigerians when it is recalled that on the 9th of January 2013, five goats were arrested in Osun State by police officers for violating environmental protection law by roaming around the residential area of Oshogbo [83]. The prospects of going to jail for environmental offenders has also been an illusion whose closest reality is the payment of a fine; a fine which is so relished.

Although several writers and authors [84] have included low-level constitutional provision for environmental protection [85] and statutory exemption from liability as the main challenges of the enforcement agencies in enforcing environmental crimes, it is safe to conclude that this position is not all together true. This first owes to the fact that even though the environmental protection in the Constitution is nonjusticiable, there exists myriads of legislation, the basis of which these criminal provisions can be enforced. Secondly, the enforcement agencies are not pinned back from doing a great work amid the statutory exemptions as not only those with immunity or beneficiaries of the exemption violate the legislation in issue. Additionally, statutory exemptions are not only peculiar to the principle of environmental crime nor is it only provided in Nigerian legislations, developed States like the United States of America and developing states like Malaysia embody them too and still applauded for enforcement rate [86]. These are mere excuses that in no way address the rise in environmental degradation and deaths that such harmful activities occasion.

While that view remains, it is apt to point out here that what the country needs is not multifarious legislation on the protection of the environment or multiple agencies whose scope of enforcement duties overlap. What the country needs is the enforcement of the already existing laws by the few existing agencies. For of what use are the many legislation when their

83 'Five Goats Arrested in Osun' The Sun Newspaper (Nigeria, 12 January 2013) <http://www.sunnewsonline.com> accessed on 28 October 2019, cited by Hakeem Ijaiya and O. T. Joseph, 'Rethinking Environmental Law Enforcement in Nigeria' [2014] Beijing Law Review (5), 278

${ }^{84}$ See Ngozi F. Stewart, 'A Proposal of Reforms for Effective Environmental Management in Nigeria' [2003], Ajayi Crowther University Law Journal, 4

${ }^{85}$ See sections 20 and 6(6) (c), Constitution of the Federal Republic of Nigeria 1999.

${ }^{86}$ Maizatun Mustafa, 'Environmental Quality Act 1974: A Tool Towards the Implementation and Achievement of Malaysia's Environmental Policy' [2011] IIUM Law Journal (14), 19 strength is sleeping on black and white papers? What are the importance of several agencies when they sleep all day and night?

To achieve the status of effective green crime enforcement, however, independent prosecutors should be attached to the office of the Director General of NESREA and they, in addition to the Director General, should be appointed and removed based on constitutional provisions; NESREA must be independent and government interference in her affairs eliminated; the states and federal governments should allocate proper funds to the environmental sector of the country with which the agencies can purchase sophisticated equipment to measure and ascertain the rate of polluting substances which are released into the environment, assess them and punish any person whose activity contravenes any regulating legislation; the requirement of a court order before investigating premises by NESREA officers should be repealed since that would have the effect of working delay in favour of the polluting facility or individual.

And to avoid the problem of environmental enforcement due to role conflicts of the enforcement agencies, certain changes are called to be made. First, it is suggested that the NOSDRA Act be repealed and its functions merged with that of NIMASA [87], and its powers expanded to include prosecution [ 88]. The Memorandum of Association on maritime spill management signed by NOSDRA and NIMASA in April 2019 is a commendable step in this respect [89]. Secondly, the NESREA Act should be amended to reflect the issue of the Agency that should be in charge of the implementation of the provisions of the Environmental Impact Act and the Harmful Waste (Special Criminal Provisions, etc) Act, rather than the current situation where such functions are carried out by the Federal Ministry of Environment.

\footnotetext{
${ }^{87}$ The rationale behind this suggestion is that NIMASA is the sole Agency recognized both locally and internationally for marine pollution control and prevention deriving its powers from both the enabling statute and the International Convention for the Prevention of Pollution of Sea by Oil.

${ }^{88}$ This is because the NIMASA Act does not empower NIMASA to prosecute matters of any kind.

$89<$ http://environnewsnigeria.com/nimasa-nosdra-signmou-on-maritime-management> accessed 29 October 2019
} 